\title{
Pengaruh Konsentrasi Larutan Perendaman Garam dan Konsentrasi Gula pada Pembuatan Selai dari Daging Buah Pala (Myristica fragrans)
}

\author{
Effect of Salt Soaking Solution Concentration and Sugar Concentration in the \\ processing of Nutmeg jam (Myristica fragrans) \\ Elva Suhendra ${ }^{1}$, Bakhtiar $^{1}$, Ismail Sulaiman ${ }^{*}$ \\ ${ }^{1}$ Program Studi Teknologi Hasil Pertanian, Fakultas Pertanian, Universitas Syiah Kuala
}

\begin{abstract}
Abstrak. Buah pala merupakan salah satu produk lokal Aceh yang dapat diolah menjadi berbagai produk makanan sampingan salah satunya adalah selai. Pada penelitian ini, variasi konsentrasi larutan perendaman garam $(\mathrm{P} ; 30 \%, 50 \%, 70 \%)$ dan konsentrasi gula $(\mathrm{G} ; 0 \%, 2,5 \%, 5 \%)$ dilakukan dengan tujuan untuk mengetahui pengaruh konsentrasi larutan perendaman garam dan konsentrasi gula pada pembuatan selai daging buah pala dengan menggunakan rancangan acak lengkap (RAL) 2 faktor dengan 3 kali perulangan. Pada penelitian ini perlakuan konsentrasi larutan perendaman garam 5\% dan konsentrasi gula 70\% (P3G3) menghasilkan rendemen $52,62 \%$, total padatan terlarut $66,19^{\circ} \mathrm{Brix}$, kadar vitamin C $0,29 \mathrm{mg}$, kadar air $25,05 \%$, uji organoleptik hedonik (warna, aroma, rasa) terbaik dan uji ranking tertinggi. Hasil penelitian menunjukkan bahwa konsentrasi larutan perendaman garam $(\mathrm{P})$ berpengaruh sangat nyata $(\mathrm{P} \leq 0,01)$ terhadap hedonik rasa selai pala. Konsentrasi gula $(\mathrm{G})$ berpengaruh nyata $(P \leq 0,05)$ terhadap kadar air, serta berpengaruh sangat nyata $(P \leq 0,01)$ terhadap rendemen, total padatan terlarut, hedonik rasa, dan aroma dari selai pala yang dihasilkan. Interaksi antara konsentrasi larutan perendaman garam dan konsentrasi gula $(\mathrm{PG})$ berpengaruh nyata $(\mathrm{P} \leq 0,05)$ terhadap rendemen dan rasa.
\end{abstract}

Kata kunci: selai, pala, garam, gula.

\begin{abstract}
Nutmeg is one of Acehnese local products that can be processed into various food products. One of them is nutmeg jam. In this study, different percentage of salt immersed solution (P; 30\%, 50\%, 70\%) and sugar concentration $(\mathrm{G} ; 0 \%, 2.5 \%, 5 \%)$ were used to examine the effect of both factors in the production of nutmeg jam using two factors completely randomized design (CRD) with three replicates. In this experiment, the P3G3 treatment (5\% salt immersed solution and 70\% sugar concentration) had 52,62\% yield, $66,19{ }^{0}$ Brix total dissolved solids, $0,29 \mathrm{mg}$ vitamin $\mathrm{C}$ content, $25,05 \%$ water content, the best hedonic organoleptic (color, aroma, taste) test and the highest ranking test. The results showed that the percentage of salt immersed solution (P) was highly significant $(P \leq 0,01)$ against the hedonic (taste) of the nutmeg jam. The sugar concentration $(\mathrm{G})$ was significant $(P \leq 0,05)$ against the moisture, and highly significant $(P \leq 0,01)$ against the yield, total dissolved solids, hedonic (flavor and aroma) of the nutmeg jam. The interaction between both factors (PG) was significant $(\mathrm{P} \leq 0,05)$ against the yield and hedonic (taste).
\end{abstract}

Keywords: jam, nutmeg, salt, sugar.

\section{PENDAHULUAN}

Buah pala (Myristica fragrans) merupakan produk unggulan Aceh dengan produksi berjumlah rata-rata 5,261 ton/tahun. Di Aceh, penggunaan buah pala lebih terfokus ke biji dan fulinya yaitu sebagai minyak pala, sedangkan pada dagingnya belum terlalu dimanfaatkan. Daging buah pala dapat dikembangkan menjadi beberapa produk, diantaranya sirup pala, dodol pala, manisan pala dan selai pala. Daging pala memiliki rasa sepat dan getir yang di sebabkan oleh adanya kadar tanin. Menurut Suryani (2004), kandungan tanin pada daging buah pala berkisar dari $12,34 \%-15,30 \%$. Upaya untuk menutupi rasa sepat dan getir yaitu dengan penambahan garam. Pada penelitian ini dikaji pemanfaatan daging buah pala menjadi produk selai pala. Penelitian ini bertujuan untuk mengetahui pengaruh konsentrasi larutan perendaman garam dan konsentrasi gula pada pembuatan selai daging buah pala. 


\section{Bahan dan Alat}

\section{METODE PENELITIAN}

Bahan-bahan yang digunakan dalam penelitian ini adalah daging buah pala, gula pasir, garam dan air. Buah pala yang digunakan pada penelitian ini berasal dari Labuhan Haji Timur, Kabupaten Aceh Selatan Provinsi Aceh. Buah pala yang dipilih adalah buah pala yang sudah matang atau warnanya sudah kuning pucat. Bahan-bahan kimia yang digunakan untuk analisis produk ini adalah asam sitrat, $0,01 \mathrm{~N}$ iodine, larutan titrasi asam askorbat $0,88 \mathrm{mg}$ dari Laboratorium Analisis Hasil Pertanian, Fakultas Pertanian Universitas Syiah Kuala.

Alat-alat yang digunakan dalam penelitian ini adalah pisau, baskom, blender, kain saring, kertas saring, centong, wajan, kompor, sedangkan alat yang digunakan untuk analisis produk adalah timbangan analitik, refraktormeter, oven, gelas ukur, gelas kimia, erlenmenyer, buret, cawan petri, cawan porselin, beaker gelas, penjepit cawan dan pipet tetes.

\section{Rancangan Percobaan}

Penelitian ini dilakukan dengan menggunakan Rancangan Acak Lengkap (RAL) faktorial yang terdiri dari atas 2 faktor yaitu faktor konsentrasi larutan perendaman garam (P) dan faktor konsentrasi gula $(\mathrm{G})$. Faktor konsentrasi larutan perendaman garam $(\mathrm{P})$ terdiri atas tiga taraf, yaitu $\mathrm{P} 1=0 \%, \mathrm{P} 2=2,5 \%, \mathrm{P} 3=5 \%$. Faktor konsentrasi gula $(\mathrm{G})$ terdiri atas 3 taraf yaitu $\mathrm{G} 1=30 \%, \mathrm{G} 2=50 \%, \mathrm{G} 3=70 \%$. Ulangan dilakukan sebanyak tiga kali sehingga diperoleh 27 satuan kombinasi percobaan.

\section{Prosedur Kerja}

Lapisan terluar dari kulit buah pala dikupas, kemudian ditimbang sebanyak $0,5 \mathrm{~kg}$ daging buah pala (untuk tiap perlakuan) dan direndam dalam larutan garam dengan konsentrasi $0 \%(0$ g), 2,5\% (12,5 g), 5\% (25 g) selama 20 menit, kemudian direbus dalam air yang sudah mendidih selama 15 menit, lalu bahan ditiriskan selama 2 menit. Setelah itu, daging buah pala dicincang atau potong dadu sebesar $2 \times 2 \mathrm{~cm}$. Daging buah pala dihancurkan menggunakan blender selama 1 menit dengan penambahan air 0,5 liter, hasil yang diperoleh disebut bubur daging pala. Bubur daging pala dicampur dengan gula pasir, dengan konsentrasi gula 30\% (150 g), 50\% (250 g), 70\% (350 g) kemudian diaduk selama 2 menit (persentase gula diambil dari berat daging buah pala). Setelah itu, bubur dipanaskan sampai mendidih selama 20 menit, pada suhu $70-80^{\circ} \mathrm{C}$. Mula-mula menggunakan api besar, setelah mendidih api dikecilkan untuk menjaga agar bubur tetap mendidih. Pengadukan dilakukan terus menerus selama 20 menit. Asam sitrat ditambahkan ketika bubur mendidih dan setiap 0,5 kg daging buah pala ditambah dengan 6 gram asam sitrat. Setelah bubur mendidih selama 20 menit, api dikecilkan untuk menjaga bubur tetap panas. Hasil yang diperoleh disebut dengan selai daging pala.

\section{Analisis}

Analisis yang dilakukan yaitu perhitungan rendemen, uji total padatan terlarut, uji kadar vitamin C, uji kadar air, uji organoleptik hedonik (warna, aroma, rasa) dan uji ranking.

\section{HASIL DAN PEMBAHASAN}

\section{Rendemen}

Selai pala yang dihasilkan memiliki rendemen berkisar dari 38,84\% - 52,62\%, dengan rata-rata umum 46,38\%. Analisis sidik ragam menunjukkan bahwa konsentrasi larutan perendaman garam $(\mathrm{P})$ berpengaruh tidak nyata $(\mathrm{P}>0,05)$ terhadap rendemen selai pala, 
sedangkan konsentrasi gula $(\mathrm{G})$ berpengaruh sangat nyata $(\mathrm{P} \leq 0,01)$. Adapun interaksi antara konsentrasi larutan perendaman garam dan konsentrasi gula $(P G)$ berpengaruh nyata $(P \leq 0,05)$ terhadap rendemen selai pala yang dihasilkan. Pengaruh interaksi antara konsentrasi larutan perendaman garam dan konsentrasi gula (PG) terhadap rendemen selai pala dapat dilihat pada Gambar 1.

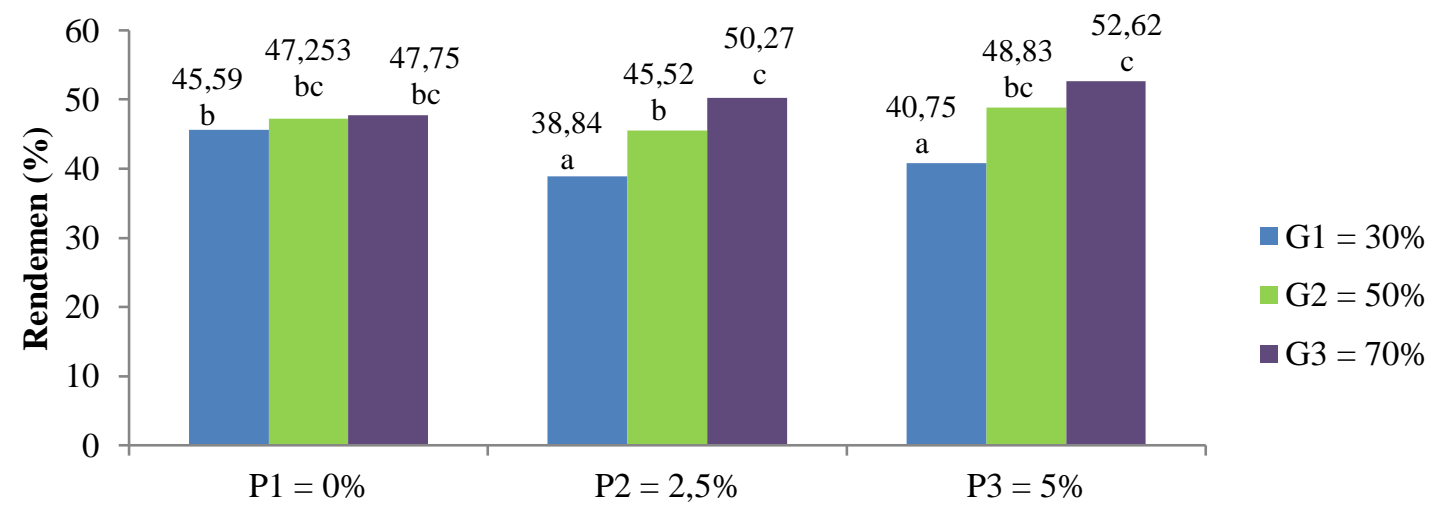

Konsentrasi Larutan Perendaman garam (P)

Gambar 1. Pengaruh interaksi antara konsentrasi larutan perendaman garam dan konsentrasi gula (PG) terhadap rendemen selai pala $\left(\mathrm{BNT}_{0,05}=4,18 ; \mathrm{KK}=5,26 \%\right)$. Huruf yang sama menunjukkan perbedaan yang tidak nyata $(\mathrm{P}>0,05)$.

Gambar 1 menunjukkan bahwa interaksi antara larutan perendaman garam 5\% dengan konsentrasi gula 70\% (P3G3) menghasilkan selai pala dengan rendemen yaitu 52,62\%, nilai ini berbeda tidak nyata dengan interaksi antara larutan perendaman garam 2,5\% dengan konsentrasi gula 70\% (P2G3) dan interaksi antara larutan perendaman garam $0 \%$ dengan kosentrasi gula 70\% (P1G3) yang menghasilkan selai pala dengan rendemen yaitu 47,75\%. Hal ini menunjukkan berapa persen pun air garam yang digunakan untuk merendam daging buah pala tidak memberikan pengaruh yang berarti terhadap rendemen yang dihasilkan dan ini juga menunjukkan bahwa perbedaan konsentrasi larutan perendaman garam hanya berguna untuk menghilangkan rasa sepat dan getir pada daging buah pala saja bukan untuk meningkatkan jumlah rendemen. Lebih lanjut, Khan dkk. (2016) juga mengatakan bahwa kekentalan dari selai berbanding lurus dengan meningkatnya konsentrasi gula yang ditambahkan. Hal ini dikarenakan gula memiliki sifat mengikat air (higroskopis), sehingga semakin banyak air yang diikat maka selai akan semakin kental.

\section{Total Padatan Terlarut}

Selai pala yang dihasilkan memiliki padatan terlarut berkisar dari 33,58-66,37 ${ }^{\circ}$ Brix, dengan rata-rata umum 49,64 ${ }^{\circ}$ Brix. Analisis sidik ragam menunjukkan bahwa konsentrasi larutan perendaman garam $(\mathrm{P})$ berpengaruh tidak nyata $(\mathrm{P}>0,05)$ terhadap padatan terlarut selai pala, sedangkan konsentrasi gula $(G)$ berpengaruh sangat nyata $(P \leq 0,01)$. Adapun interaksi antara konsentrasi larutan perendaman garam dan konsentrasi gula (PG) berpengaruh tidak nyata $(\mathrm{P}>0,05)$ terhadap padatan terlarut selai pala yang dihasilkan. Pengaruh konsentrasi gula $(\mathrm{G})$ terhadap padatan terlarut selai pala dapat dilihat pada Gambar 2. 


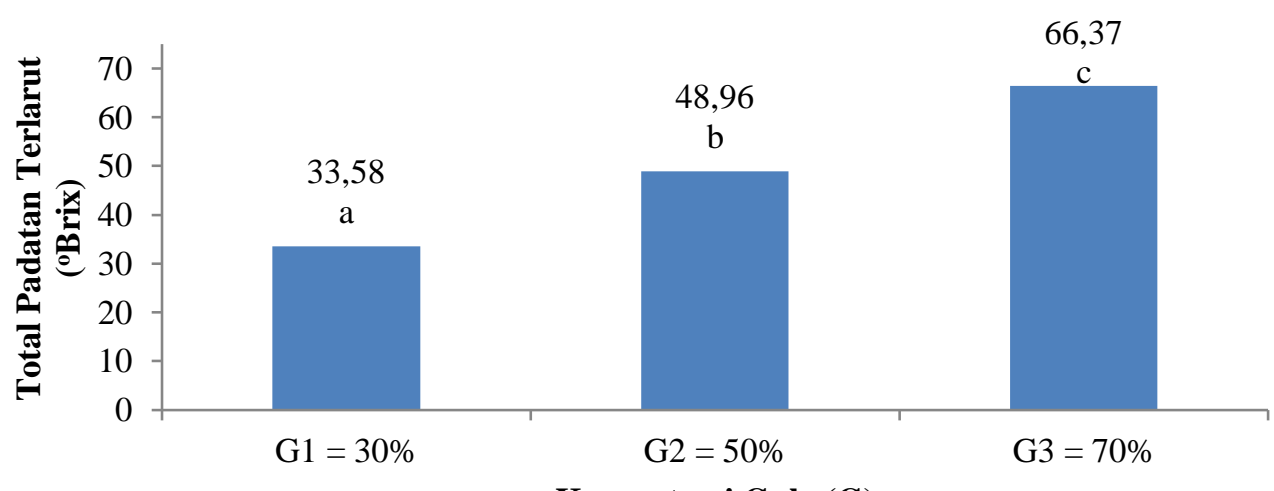

Gambar 2. Pengaruh konsentrasi gula $(\mathrm{G})$ terhadap total padatan terlarut selai pala $\left(\mathrm{BNT}_{0,01}=4,84 ; \mathrm{KK}=\right.$ $4,14 \%)$.

Gambar 2 menunjukkan bahwa konsentrasi gula 30\% (33,58 ${ }^{\circ}$ Brix) berbeda nyata dengan konsentrasi gula 50\% (48,96 ${ }^{\circ}$ Brix) dan 70\% (66,37 ${ }^{\circ}$ Brix). Perbedaan ini disebabkan total padatan terlarut meningkat seiring dengan bertambahnya konsentrasi gula yang digunakan. Ini dikarenakan penambahan gula yang lebih banyak akan meningkatkan padatan terlarut dalam selai karena gula merupakan komponen pembentuk padatan terlarut (Yulistiani dkk., 2013). Desrosier (1988) di dalam Fahrizal dan Fadil (2014) mengatakan bahwa kandungan total padatan terlarut suatu bahan meliputi gula reduksi, gula non reduksi, asam organik, pektin dan protein.

\section{Vitamin C}

Selai pala yang dihasilkan memiliki kadar vitamin $\mathrm{C}$ berkisar dari 0,17-0,44 mg, dengan rata-rata umum $0,27 \mathrm{mg}$. Analisis sidik ragam menunjukkan bahwa konsentrasi larutan perendaman garam $(\mathrm{P})$, konsentrasi gula $(\mathrm{G})$ serta interaksi antara konsentrasi larutan perendaman garam dan konsentrasi gula $(\mathrm{PG})$ berpengaruh tidak nyata $(\mathrm{P}>0,05)$ terhadap kadar vitamin $\mathrm{C}$ selai pala yang dihasilkan. Hasil ini diduga karena jumlah buah pala dan proses panas yang diberikan ke tiap perlakuan adalah sama. Besar degradasi yang diberikan oleh panas diduga sama untuk tiap perlakuan meskipun larutan perendaman garam dan gula yang digunakan berbeda konsentrasinya.

\section{Kadar Air}

Selai pala yang dihasilkan memiliki kadar air berkisar dari 20,72\% - 40,74\%, dengan rata-rata umum 29,58\%. Analisis sidik ragam menunjukkan bahwa konsentrasi larutan perendaman garam $(\mathrm{P})$ berpengaruh tidak nyata $(\mathrm{P}>0,05)$ terhadap kadar air selai pala, sedangkan konsentrasi gula $(\mathrm{G})$ berpengaruh sangat nyata $(\mathrm{P} \leq 0,01)$. Adapun interaksi antara konsentrasi larutan perendaman garam dan konsentrasi gula $(\mathrm{PG})$ berpengaruh tidak nyata $(\mathrm{P}>0,05)$ terhadap kadar air selai pala yang dihasilkan. Pengaruh konsentrasi gula (G) terhadap kadar selai pala dapat dilihat pada Gambar 3.

Gambar 3 menunjukkan bahwa Kadar air selai pala dengan konsentrasi gula 30\% (G1) berbeda tidak nyata dengan konsentrasi gula $50 \%$ (G2) namun berbeda nyata dengan konsentrasi gula 70\% (G3). Penurunan kadar ini disebabkan karena gula dapat mengikat air bebas menjadi air terikat sehingga kadar air yang terukur (teruapkan) menjadi lebih rendah. 


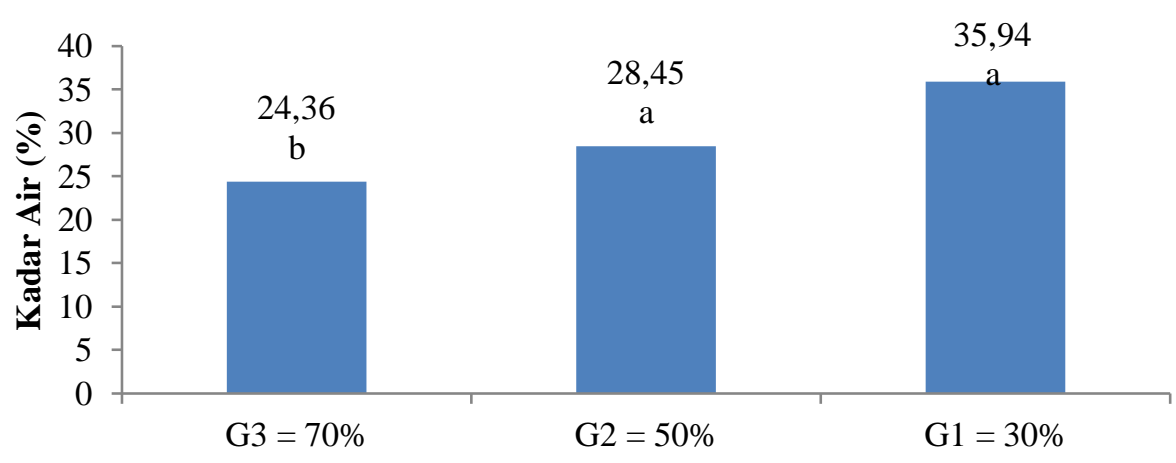

Konsentrasi Gula (G)

Gambar 3. Pengaruh konsentrasi gula $(\mathrm{G})$ terhadap kadar air selai pala $\left(\mathrm{BNT}_{0,01}=7,14 ; \mathrm{KK}=10,26 \%\right)$. Huruf yang sama menunjukkan perbedaan yang tidak nyata $(\mathrm{P}>0,05)$.

\section{Hedonik Warna}

Selai pala yang dihasilkan memiliki skala hedonik warna berkisar dari 3,13 (netral) 3,70 (suka), dengan rata-rata umum 3,49 (netral). Analisis sidik ragam menunjukkan bahwa konsentrasi larutan perendaman garam (P), konsentrasi gula (G) serta interaksi antara konsentrasi larutan perendaman garam dan konsentrasi gula (PG) berpengaruh tidak nyata nyata $(\mathrm{P}>0,05)$ terhadap hedonik warna selai pala yang dihasilkan. Hal ini dikarenakan reaksi antara gula dan panas menyebabkan selai memiliki warna kecoklatan yang sama untuk masing-masing perlakuan. Warna kecoklatan muncul karena reaksi karamelisasi pada gula (Winarno, 2004 dalam Yunita, 2013).

\section{Hedonik Aroma}

Selai pala yang dihasilkan memiliki skala hedonik aroma berkisar dari 2,77 (netral) 3,70 (suka), dengan rata-rata umum 3,33 (netral). Analisis sidik ragam menunjukkan bahwa konsentrasi larutan perendaman garam $(\mathrm{P})$ berpengaruh tidak nyata $(\mathrm{P}>0,05)$ terhadap hedonik aroma selai pala, sedangkan konsentrasi gula $(\mathrm{G})$ berpengaruh sangat nyata $(\mathrm{P} \leq 0,01)$. Interaksi antara konsentrasi larutan perendaman garam $(\mathrm{P})$ dan konsentrasi gula $(\mathrm{G})$ juga berpengaruh tidak nyata $(\mathrm{P}>0,05)$ terhadap hedonik aroma selai pala yang dihasilkan. Pengaruh konsentrasi gula $(\mathrm{G})$ terhadap hedonik aroma selai pala yang dihasilkan. Pengaruh konsentrasi gula $(\mathrm{G})$ terhadap hedonik aroma selai pala dapat dilihat pada Gambar 4.

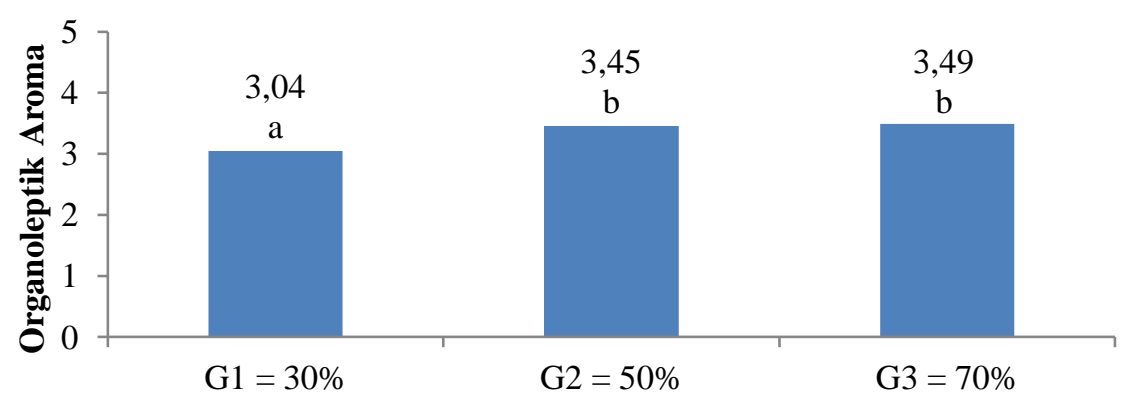

Konsentrasi Gula (G)

Gambar 4. Pengaruh konsentrasi gula $(\mathrm{G})$ terhadap hedonik aroma selai pala $\left(\mathrm{BNT}_{0,05}=0,35 ; \mathrm{KK}=4,43 \%\right)$. Huruf yang sama menunjukkan perbedaan yang tidak nyata $(\mathrm{P}>0,05)$. 
Gambar 4 menunjukkan bahwa aroma yang paling disukai oleh panelis adalah selai dengan konsentrasi gula 70\% (G3) yaitu 3,49. Namun, secara statistik selai dengan konsentrasi gula 50\% (G2) yaitu 3,45 tidak berbeda dengan konsentrasi gula 70\% (G3). Adapun selai pala dengan konsentrasi gula $30 \%$ (G1) merupakan sampel yang netral aromanya yaitu $3,04 \%$. Hal ini dikarenakan gula berperan dalam perbaikan aroma suatu produk.

\section{Hedonik Rasa}

Selai pala yang dihasilkan memiliki skala hedonik rasa berkisar dari 2,43 (tidak suka) 3,60 (suka), dengan rata-rata umum 3,19 (netral). Analisis sidik ragam menunjukkan bahwa konsentrasi larutan perendaman garam $(\mathrm{P})$ dan konsentrasi gula $(\mathrm{G})$ berpengaruh sangat nyata terhadap hedonik rasa selai pala $(\mathrm{P} \leq 0,01)$. Adapun interaksi antara konsentrasi larutan perendaman garam dan konsentrasi gula $(\mathrm{PG})$ berpengaruh nyata $(\mathrm{P} \leq 0,05)$ terhadap hedonik rasa selai pala yang dihasilkan. Pengaruh interaksi antara konsentrasi larutan perendaman garam dan konsentrasi gula (PG) terhadap hedonik rasa selai pala dapat dilihat pada Gambar 5 .

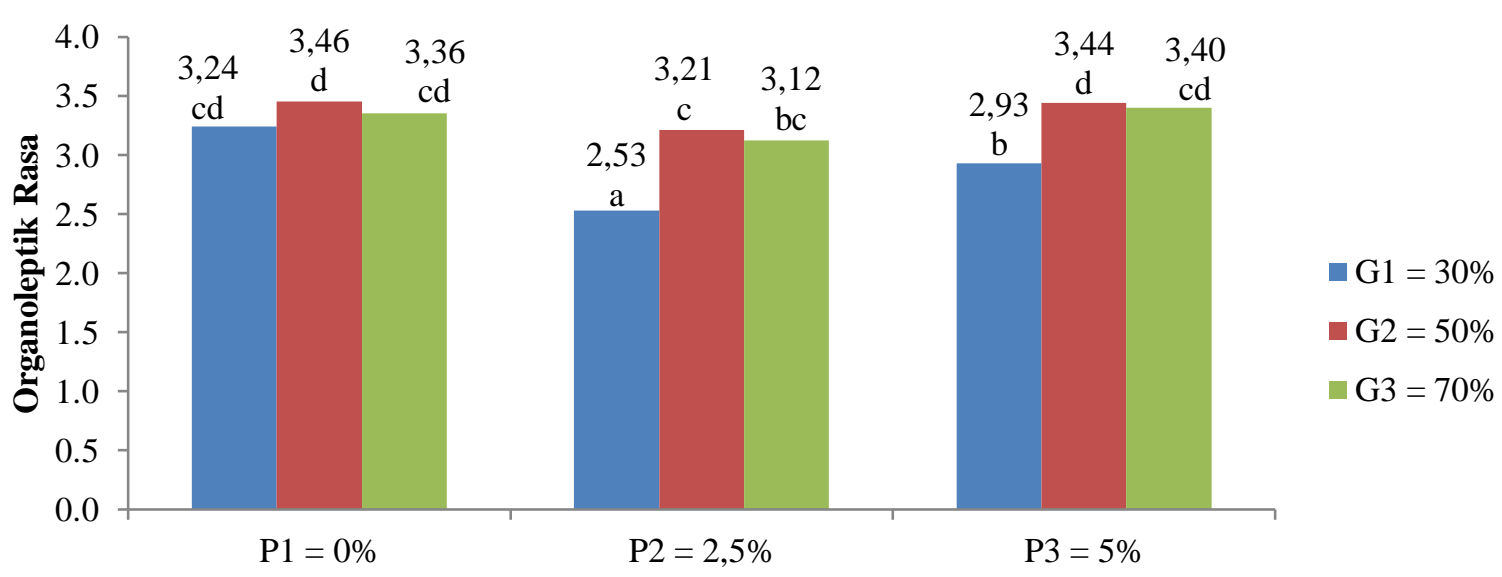

Konsentrasi Larutan Perendaman Garam (P)

Gambar 5. Pengaruh interaksi antara konsentrasi larutan perendaman garam dan konsentrasi gula (PG) terhadap hedonik rasa selai pala $\left(\mathrm{BNT}_{0,05}=0,23 ; \mathrm{KK}=4,15 \%\right)$. Huruf yang sama menunjukkan perbedaan yang tidak nyata $(\mathrm{P}>0,05)$.

Gambar 5 menunjukkan bahwa panelis menyukai selai pala dengan penambahan gula $50 \%$ pada masing-masing konsentrasi larutan perendam garam dan penambahan gula $70 \%$. Ini menunjukkan bahwa rata-rata panelis menyukai selai pala yang tingkat kemanisannya medium, yaitu antara 50\% dan $70 \%$. Hal ini diduga karena selai pala pada konsentrasi gula $30 \%$ memiliki tingkat kemanisan yang rendah dan sebaliknya konsentrasi gula 50\% dan 70\% memiliki tingkat kemanisan yang lebih tinggi. Oleh karena itu, panelis menyukai selai pala dengan konsentrasi gula $50 \%$ dan $70 \%$. 


\section{KESIMPULAN DAN SARAN}

\section{Kesimpulan}

1. Konsentrasi larutan perendaman $(\mathrm{P})$ berpengaruh sangat nyata $(\mathrm{P} \leq 0,01)$ terhadap hedonik rasa selai pala.

2. Konsentrasi gula $(\mathrm{G})$ berpengaruh nyata $(\mathrm{P} \leq 0,05)$ terhadap kadar air, serta berpengaruh sangat nyata $(\mathrm{P} \leq 0,01)$ terhadap rendemen, total padatan terlarut, hedonik rasa, dan hedonik aroma dari selai pala yang dihasilkan.

3. Interaksi antara konsentrasi larutan perendaman garam dan konsentrasi gula (PG) berpengaruh nyata $(\mathrm{P} \leq 0,05)$ terhadap rendemen dan hedonik rasa.

4. Berdasarkan uji hedonik, tingkat kesukaan panelis terhadap selai pala yaitu berkisar dari netral-suka $(3,01-3,53)$ untuk masing-masing warna, aroma dan rasa.

5. Selai daging buah pala dengan perlakuan terbaik terdapat pada kombinasi konsentrasi larutan perendaman garam 5\% dan konsentrasi gula 70\% (P3G3), dengan rendemen $52,62 \%$, total padatan terlarut $66,19^{\circ}$ Brix, vitamin C 0,29 mg dan kadar air 25,05\%. Selai daging buah pala telah memenuhi SNI dengan kriteria total padatan terlarut yaitu 65 ${ }^{0}$ Brix.

\section{Saran}

1. Perlu dilakukan penelitian perbandingan larutan perendaman garam dengan perlakuan yang lain seperti larutan kapur dan natrium metabisulfit.

2. Perlu dilakukan perhitungan pendugaan masa simpan selai daging buah pala.

\section{DAFTAR PUSTAKA}

BSN. 2008. Selai Buah. SNI 3746. Badan Standardisasi Nasional, Jakarta.

Departemen Pertanian. 2004. Pala Miristica fragrans. Direktorat Pengolahan dan Pemasaran Hasil Perkebunan. Direktorat Jenderal Bina Pengolahan dan Pemasaran Hasil Pertanian.

Dinas Kehutanan dan Perkebunan Aceh. 2011. Pala Miristica fragrans. Direktorat Pengolahan dan Pemasaran Hasil Perkebunan. Direktorat Jenderal Bina Pengolahan dan Pemasaran Hasil Pertanian.

Direktorat Bina Pengolahan dan Pemasaran Hasil Pertanian. 2004. Pembuatan Selai. http://docs.google.com.

Fahrizal dan Fadhil, R. 2014. Kajian Fisiko Kimia dan Daya Terima Organoleptik Selai Nenas yang Menggunakan Pektin dari Limbah Kulit Kakao.Jurnal Teknologi dan Industri Pertanian Vol.6 No.3 Hal.65-68.

Gaspersz, V. 1991. Metode Perancangan Percobaan. Armico, Bandung.

Khan, A.A., S.W. Ali, K. Rehman, S. Manzoor, S.R. Ayub, dan M. Ilyas. 2016. Influence of Sugar Concentration on Physicochemical Properties and Sensory Attributes of Sapodilla Jam.University of Punjab, Lahore.

Suryani, A. 2004. Membuat Aneka Selai. Penebar Swadaya, Jakarta. 
Yulistiani, R., Murtiningsih dan M. Mahmud. 2013. Peran Pektin dan Sukrosa pada Selai Ubi Jalar Ungu (The Role of Pectin and Sucrose on Purple Sweet Potato Jam). Universitas UPN Jawa Timur, Surabaya.

Winarno, F. G, 2004. Pengantar Teknologi Pangan. Gramedia Pustaka Utama, Jakarta. 